\title{
DIVERSIFIKASI TALAS BOGOR (Colocasia Esculenta (L) Schott) SEBAGAI UPAYA OLAHAN PRODUK TAPAI KHAS BOGOR
}

\author{
Antony Rendi Sanjaya ${ }^{1}$, Ade Heri Mulyati ${ }^{*}$, Padmono Citroreksoko ${ }^{1}$ \\ ${ }^{1}$ Program Studi Kimia FMIPA Universitas Pakuan, Bogor \\ *Email: adeherimulyati@yahoo.com
}

diterima: 6 Juli 2018; direvisi:8 Agustus 2018; disetujui:14 September 2018

\begin{abstract}
ABSTRAK
Di kabupaten Bogor sebagai sentra produksi talas Indonesia, tercatat produksinya sekitar 57.000 ton pada tahun 2008. Umbi talas Bogor yang jumlahnya melimpah di kota Bogor masih terbatas pemanfaatannya. Keberagaman pemanfaatan umbi talas diperlukan agar memaksimalkan sumber daya yang ada dan dapat menjadi produk olahan alternatif di pasaran. Kandungan karbohidrat pada talas Bogor (Colocasia Esculenta (L) Schott) berdasarkan data dari Direktorat Gizi Depkes RI pada tahun 2008 sebesar 23,79\%, kandungan karbohidrat talas yang tinggi menjadikan talas dapat diolah menjadi makanan khas yang disebut tapai sebagai upaya penganekaragaman olahan talas. Penelitian ini bertujuan untuk mengetahui pengaruh jenis tapai yang digunakan dan waktu fermentasi optimum untuk menghasilkan produk tapai yang terbaik. Metode penelitian yaitu pembuatan tapai dari tiga jenis talas yang berbeda talas bentul, talas mentega dan talas sutra kemudian difermentasikan dengan waktu yang berbeda, yaitu selama 48, 72 dan 96 jam. Setelah didapatkan produk yang disukai panelis, dilakukan pengujian kualitas produk dilihat dari parameter derajat keasaman $(\mathrm{pH})$, gula reduksi, karbohidrat, alkohol yang dihasilkan serta serat pangan yang terkandung. Tapai talas bentul dengan waktu fermentasi selama 48 jam merupakan produk terpilih dan digunakan sebagai variable tetap dalam penelitian selanjutnya. Hasil analisis kimia tapai talas bentul (B1) memiliki kadar air sebesar 59.27\%, abu $2.11 \%$, lemak $1.78 \%$, protein $2.96 \%$, karbohidrat $21.94 \%$, gula total $13.99 \%$, alcohol $6.03 \%$, serat pangan $2.28 \%$ dan nilai $\mathrm{pH}$ sebesar 5.48 .
\end{abstract}

Kata Kunci: alkohol, fermentasi, gula, talas Bogor, tapai

\begin{abstract}
In Bogor district as an Indonesian taro central production, recorded that it has almost 57000 ton taro each year in 2008. Bogor's taro which is abundant in Bogor is still limited its use. Diversity the use of taro necessary to maximize available resources and make it becoming alternative processed products in market. Carbohydrat content in Bogor's taro depends on data from Nutrition Directorate of Ministry of Health in 2008 is $23.79 \%$, the high content of carbohydrate makes taro can be processed to a characteristic food such as tapai. This research aims to knowing type of taro's effect to product and optimum fermentation time to make best tapai product. Research method begins with making tapai from three kind of taro, they are bentul taro, mentega taro and sutra taro. Then it fermentated at different time length, 48 hours, 72 hours and 96 hours. After get the best product that liked by the panellist, conducted quality testing seen from moisture, ash content, total fat, protein, $\mathrm{pH}$, reduction sugar, carbohydrate content, alcohol content and dietary fibre. Tapai bentul taro with fermentation length 48 hours is chosen and it use as a remain variable. The result of chemical analysis tapai bentul taro (B1) are moisture $59.27 \%$, ash content $2.11 \%$, total fat $1.78 \%$, protein $2.96 \%$, pH 5.48, reduction sugar $12.13 \%$, carbohydrate $21.94 \%$, alcohol $6.03 \%$ and dietary fibre $2.28 \%$.
\end{abstract}

Key words: alcohol, Bogor Taro, fermentation, sugar, tapai 


\section{PENDAHULUAN}

Di Kabupaten Bogor sebagai sentra produksi talas Indonesia, tercatat produksinya sekitar 57.000 ton pada tahun 2008 (Julianto, 2014). Umbi talas Bogor yang jumlahnya melimpah di kota Bogor masih terbatas pemanfaatannya (Indastri, 2004). Salah satunya hanya dijadikan bahan baku pembuatan kue, talas kukus dengan parutan kelapa sebagai pelengkap hidangan atau dengan membuat olahan keripik dari talas (Kuswara, 2002).

Keberagaman pemanfaatan umbi talas diperlukan agar memaksimalkan sumber daya yang ada dan dapat menjadi produk olahan alternatif di pasaran. Kandungan karbohidrat pada talas Bogor (Colocasia Esculenta (L) Schott) berdasarkan data dari Direktorat Gizi Depkes RI pada tahun 2008 sebesar 23,79\%, kandungan karbohidrat talas yang tinggi menjadikan talas dapat diolah menjadi makanan khas yang disebut tapai sebagai upaya penganekaragaman olahan talas. Bahan pangan yang umumnya dibuat tapai adalah ubi kayu (singkong), beras ketan putih maupun beras ketan hitam serta sorgum (Rukmana dan Yuniarsih, 2001).

Tapai adalah makanan yang difermentasikan sehingga mengalami perubahan dan menghasilkan rasa yang manis dan mengandung alkohol dalam keadaan anaerob dengan bantuan jamur atau ragi. Selama ratusan tahun ragi (yeast) telah digunakan dalam pembuatan roti. Sebelum ragi diproduksi secara komersial, dahulu orang membuat sourdough dan country breads menggunakan ragi dari hasil fermentasi anggur dan/ atau kentang. Sejak abad 18, saat ilmuwan Louis Pasteur melakukan penelitian maka diketahuilah keberadaan mikroorganisme ragi yang berguna dan menguntungkan umat manusia.

Salah satu hasil dari pemanfaatan talas bogor ialah pembuatan tapai, dengan cara memperpanjang umur pakai dari talas tersebut melalui metode fermentasi yang ditambahkan ragi untuk membantu penguraian terhadap pati menjadi gula.

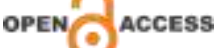

Sebelum talas dibuat tapai, terlebih dahulu talas di kupas kulitnya serta dipotong batangnya yang kemudian dicuci untuk menghilangkan getah serta mengurangi kadar senyawa oksalat yang ada dalam talas tersebut. Kalsim oksalat hanya menyebabkan gatal tanpa gangguan lain. Zat tersebut dapat dikurang dengan pencucian banyak air (Sitompul dan Guritno, 1995).

Talas direndam dalam larutan natrium klorida $(\mathrm{NaCl})$ yang kemudian dibilas dengan air bersih untuk menghilangkan kotoran pada talas tersebut. Jarum-jarum kristal kalsium oksalat penyebab rasa gatal dapat juga dihilangkan dengan pencucian dan perendaman beberapakali secara tepat (Lingga, 1989). Talas yang telah dicuci dan dibilas, kemudian dipotong sesuai keinginan yang selanjutnya dilakukan proses pengukusan untuk memperoleh talas yang empuk serta untuk mempermudah ragi mengurai pati yang ada. Selanjutnya adalah proses fermentasi, ragi yang sudah dihaluskan ditaburi kedalam talas kemudian ditempatkan pada wadah yang sudah dilapisi daun pisang. Setelah itu talas yang telah ditaburi ragi, dilapisi daun pisang sebelum difermentasi pada wadah yang tertutup selama \pm 3 hari.

Tapai umumnya mempunyai tekstur yang lunak, berair, bertekstur lengket dan lembut (Santosa, 2010). Hal ini disebabkan karena dalam proses fermentasi terjadi penguraian gula sederhana menjadi alkohol yang disertai dengan pelepasan kandungan air, sehingga air dalam bahan makanan semakin meningkat dan menyebabkan tekstur dari tapai tersebut menjadi sangat lunak (Astawan. 2004).

\section{BAHAN DAN METODE}

Penelitian ini dilakukan melalui beberapa tahapan yaitu, penelitian diawali dengan pemilihan atau pengambilan sampel umbi talas Bogor di daerah dramaga, Kabupaten Bogor. Penelitian pendahuluan dilakukan untuk menentukan jenis talas dan waktu fermentasi yang menghasilkan produk tapai yang disukai oleh panelis. Penelitian 
pendahuluan ini menggunakan 3 jenis talas: Talas Bentul, Mentega dan Sutra, dengan waktu fermentasi pada waktu 48, 72 dan 96 jam.

Tabel 1. Formulasi jenis talasdan waktu fermentasi

\begin{tabular}{cccc}
\hline Waktu & \multicolumn{3}{c}{ Jenis Talas } \\
\cline { 2 - 4 } $\begin{array}{c}\text { Fermentasi } \\
(\text { Jam })\end{array}$ & Talas & Talas & Talas \\
Bentul & Mentega & Sutra \\
\hline 48 & B1 & M1 & S1 \\
72 & B2 & M2 & S2 \\
96 & B3 & M3 & S3 \\
\hline
\end{tabular}

Hasil formulasi pada Tabel 1, kemudian dari dilakukan uji organoleptik pada panelis hingga didapatkan tapai yang paling disukai. Formula yang terpilih dilakukan pengujian kadar gula reduksi, karbohidrat, alkohol, nilai $\mathrm{pH}$, protein, lemak, air, abu dan serat pangan.

\section{Pembuatan Tapai Talas}

Pembuatan tapai talas Bogor dilakukan dengan metode fermentasi, ketiga jenis talas yang telah disortir kemudian dikupas kulitnya dan dicuci sampai bersih hingga lendirnya berkurang. Kemudian talas dipotong balok kecil, setelah itu talas direndam dengan larutan natrium klorida $10 \%$ selama 60 menit. Talas yang telah direndam kemudian dicuci untuk menghilangkan sisa larutan perendam. Talas dikeringkan lalu dikukus untuk membuat tekstur talas menjadi lebih empuk dan talas tersebut diangkat untuk didinginkan.

Talas yang telah dingin ditempatkan dalam sebuah wadah yang dilapisi daun pisang yang sudah dibersihkan. Setelah itu, ragi ditaburi secara merata dengan formula yang telah ditentukan kemudian wadah ditutup rapat dengan waktu 48, 72 dan 96 jam untuk memaksimalkan proses fermentasi.

\section{HASIL DAN PEMBAHASAN Determinasi Tanaman}

Determinasi tanaman dilakukan pada sampel talas meliputi daun, batang, buah dan biji talas untuk mengetahui jenis atau spesies talas yang digunakan untuk penelitian ini. Hasil determinasi yang dilakukan di Herbarium Bogoriense, Bidang Botani Pusat Penelitian Biologi - LIPI Bogor adalah menunjukkan species Colocasia esculenta yang termasuk dalam Famili Araceae.

\section{Karakteristik Kimia Talas}

Talas dari mulai daun dan umbinya mempunyai kandungan gizi yang cukup baik (Tabel 2). Talas mengandung unsur mineral dan vitamin, sehingga dapat dijadikan obat-obatan serta umbi talas juga berpotensi sebagai sumber karbohidrat dan protein yang cukup tinggi.

Tabel 2. Karakteristik Kimia Talas

\begin{tabular}{lccl}
\hline \multirow{2}{*}{ Parameter } & \multicolumn{3}{c}{ Jenis Talas } \\
\cline { 2 - 4 } & Bentul & Mentega & Sutra \\
\hline $\mathrm{pH}$ & 7.0 & 6.20 & 6.31 \\
\hline Karbohidrat (\%) & 23.59 & 14.29 & 20.36 \\
\hline Kadar Air (\%) & 58.75 & 78.25 & 68.24 \\
\hline Gula Reduksi (\%) & 0.25 & 0.24 & 0.47 \\
\hline Gula Total (\%) & 0.99 & 0.98 & 1.90 \\
\hline Alkohol $(\%)$ & 1.22 & 1.33 & 1.06 \\
\hline
\end{tabular}

Umbi talas juga mengandung lemak, vitamin B1 dan sedikit vitamin C (Richana. 2012).

\section{Karakteristik Fisik Tapai Talas}

Berdasarkan hasil uji hedonik, talas bentul dengan waktu fermentasi 48 jam menjadi favorit bagi para panelis. Hasil pengamatan tapai talas bentul saat umur fermentasi 48 jam ada pada Tabel 3 .

Tabel 3. Karakteristik Fisika Tapai Talas

\begin{tabular}{cccc}
\multirow{2}{*}{ Parameter } & \multicolumn{3}{c}{ Jenis Tapai } \\
\cline { 2 - 4 } & Bentul & Mentega & Sutra \\
\hline Aroma & Khas tapai & Khas tapai & Khas \\
& & & tapai \\
Tekstur & Lunak & Lunak & Lunak \\
Warna & Putih abu- & Putih abu- & Putih \\
& abu & abu & abu- abu \\
Rasa & Manis & Sedikit & Netral \\
& & manis \\
\hline
\end{tabular}


Aroma tapai merupakan hasil uap dari proses pengolahan makanan, uap ini tercipta dari bahan- bahan makanan yang diolah. Aroma khas tapai yang berbau tajam ini berasal dari ragi yang berkerja dalam proses fermentasi yang merombak zat pati menjadi alkohol (Santosa, 2010). Tapai umumnya mempunyai tekstur yang lunak, berair, bertekstur lengket dan lembut (Santosa, 2010). Warna juga menjadi salah satu faktor untuk menentukan mutu secara kasat mata atau visual, warna dari tapai ini juga dipengaruhi oleh waktu perebusan sebelum difermentasi.

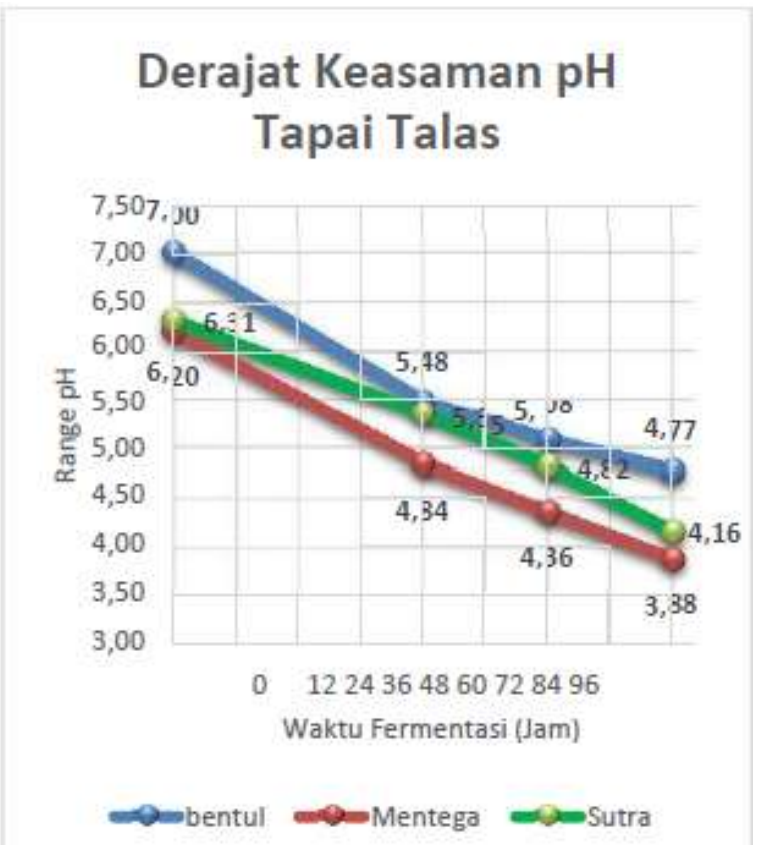

Gambar 1. Derajat Keasaman PH Tapai Talas

\section{Karakteristik pH Tapai Talas}

Penetapan kadar $\mathrm{pH}$ dilakukan dengan menggunakan $\mathrm{pH}$ meter yang sudah terkalibrasi dengan baik. Pada Gambar 1. hasil uji untuk nilai $\mathrm{pH}$ tapai talas bentul tercatat nilai $\mathrm{pH} 7$ dan terjadi penurunan setelah 48 jam fermentasi talas bentul sampai pada nilai $\mathrm{pH} 5,48$. Terjadinya penurunan nilai $\mathrm{pH}$ dikarenakan adanya aktifitas fermentasi, semakin lama waktu fermentasinya maka akan lebih meningkatkan tingkat derajat keasaman, ketika waktu fermentsi mencapai 72 jam kandungan nilai $\mathrm{pH}$ semakin menurun tercatat pada tabel 5 sebesar 5,08 dan pada waktu 96 jam fermentasi nilai $\mathrm{pH}$ mencapai 4,77. Hal ini disebabkan karena gula yang telah terurai menjadi alkohol, kemudian bakteri dalam ragi tersebut memecah alkohol menjadi asam asetat. Alkohol yang berasal dari fermentasi ragi, dengan adanya oksigen (O2) akan mengalami fermentasi lebih lanjut oleh bakteri Acetobacter Aceti yang kemudian menghasilkan asam asetat (Suwaryono, 1987).

\section{Karakteristik Kimia Karbohidrat Tapai Talas}

Penetapan kadar karbohidrat dilakukan dengan metode Luff-Schrool, hasil uji tapai talas bentul yang tercatat adalah $23.59 \%$ untuk kadar karbohidrat yang tercatat pada setelah 48 jam fermentasi terjadi penurunan menjadi $21.94 \%$ semakin lamanya waktu fermentasi semakin berkurang kadar karbohidrat nya, pada 72 jam fermentasi tercatat $21.01 \%$ lalu pada 96 jam fermentasi tercatat sebesar $20.55 \%$ kadar tapai talas bentul (Gambar 2). Hal ini disebabkan adanya aktifitas fermentasi, dimana mikroorganisme dari kapang seperti Amylomyces rouxii, Mucor sp. dan Rhizopus $s p$. yang menghasilkan enzim-enzim amilolitik yang akan memecah amilum pada talas menjadi gula-gula yang lebih sederhana (sukrosa, laktosa dan maltosa). Proses ini biasa disebut dengan proses sakarifikasi, kemudian kelompok mikroorganisme khamir akan merubah gula yang sederhana tersebut menjadi alkohol.

\section{Karakteristik Kimia Alkohol Tapai Talas}

Penetapan kadar alkohol dilakukan dengan metode Skoog (1985). Pada Gambar 3 tercatat hasil uji tapai talas bentul sebesar $1.22 \%$ untuk kadar alkohol tapai talas bentul mengalami kenaikan menjadi $6.03 \%$ dalam 48 jam fermentasi dan saat 72 jam ferementasi mencapai $7.93 \%$ sampai saat 96 jam fermentasi mengalami kenaikan mencapai $11.46 \%$. 


\section{Karbohidrat Tapai Talas}

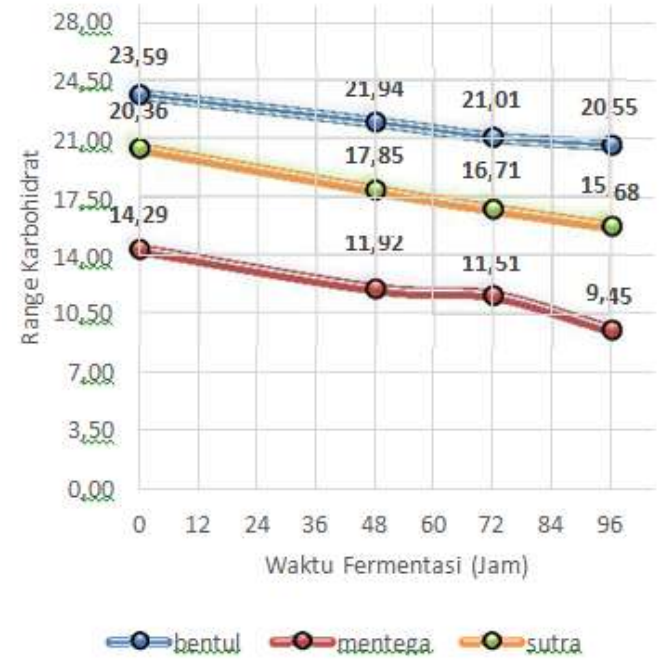

Gambar 2. Karakteristik Kimia Karbohidrat Tapai Talas

\section{Kadar Alkohol Tapai Talas}

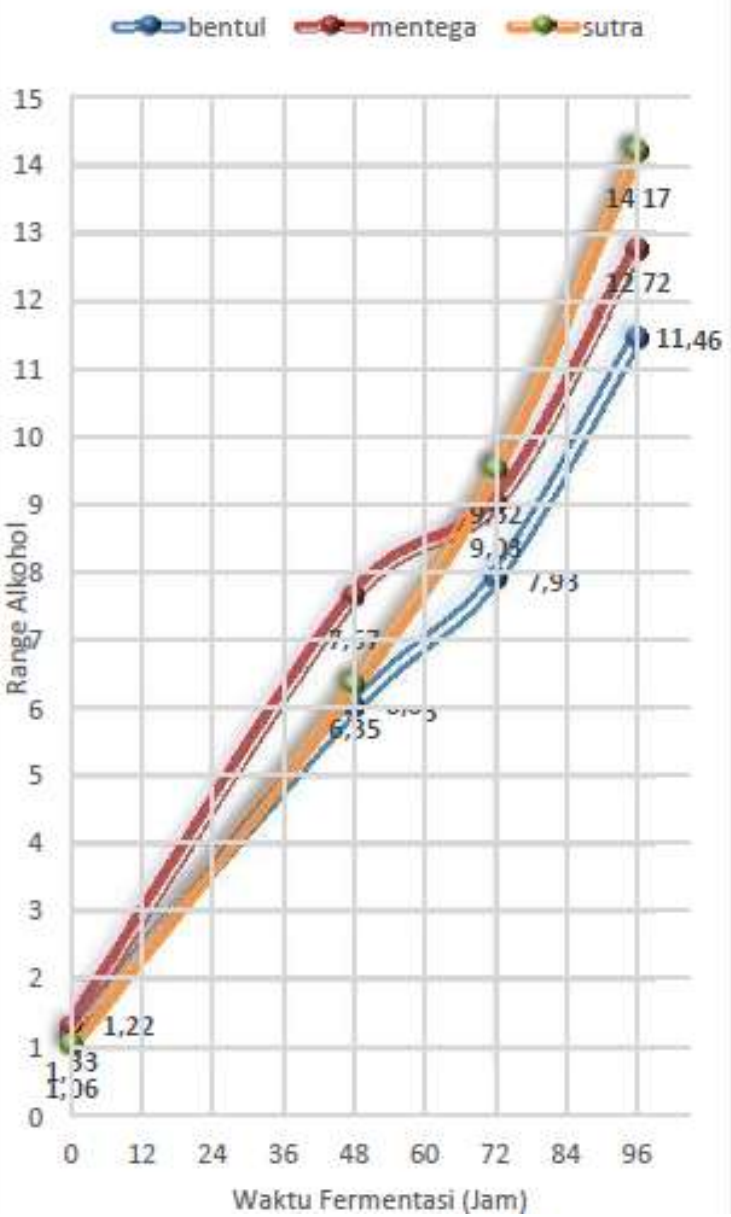

Gambar 3. Kadar Alkohol Tapai Talas

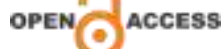

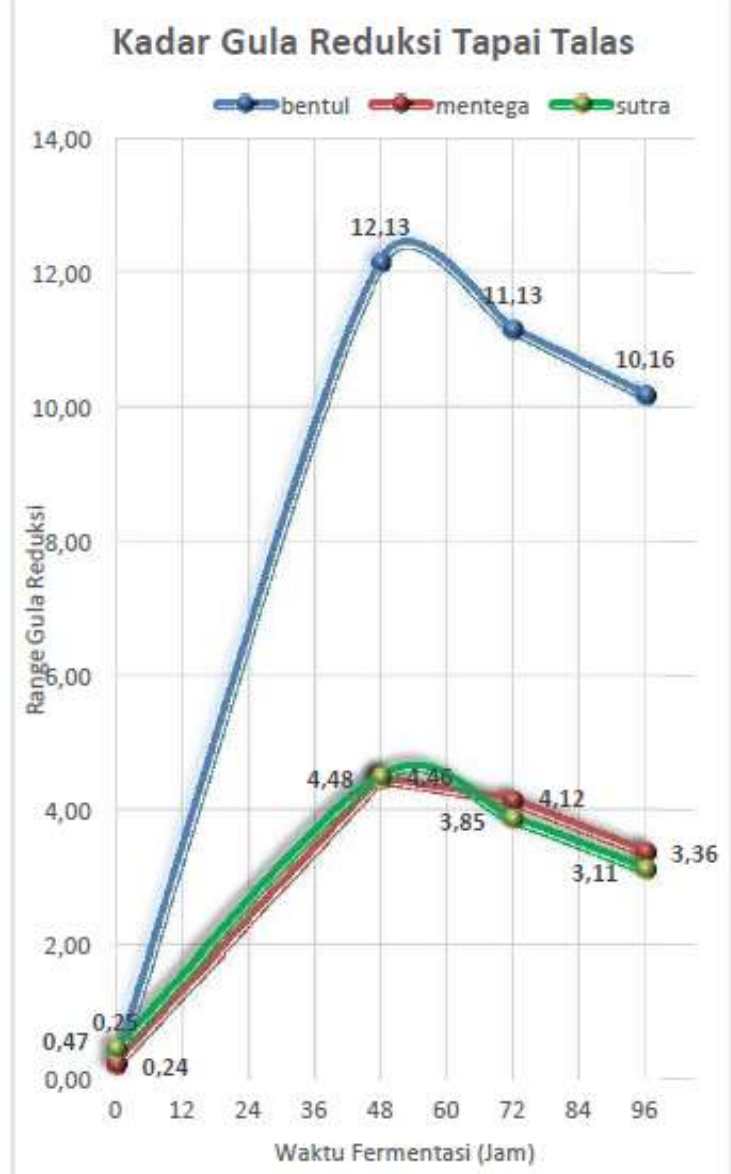

Gambar 4. Kadar Gula Reduksi Tapai Talas

Hal ini karena proses fermentasi yang terus berjalan, selama proses fermentasi kelompok mikroorganisme khamir seperti Saccaromyces cerevicae menkonversi gulagula sederhana (glukosa, galaktosa dan fruktosa) menjadi alkohol. Mikroorganisme ini menghasilkan enzim zimase dan invertase, enzim zimase berfungsi sebagai pemecah sukrosa menjadi monosakarida (glukosa dan fruktosa) lalu enzim invertase mengubah glukosa tersebut menjadi alkohol dengan lama fermentasi 30 - 70 jam dalam kondisi anaerob (Judoamidjojo, 1992). Semakin lama fermentasi maka akan semakin banyak glukosa yang dirombak menjadi alkohol, sehingga kadar alkohol yang dihasilkan semakin tinggi (Setyohadi, 2006).

\section{Karakteristik Kimia Gula Reduksi}

Penetapan kadar gula reduksi dengan menggunakan metode (SNI 01-2893-1992), pada Gambar 4, hasil uji tapai talas bentul 
tercatat saat 48 jam fermentasi mencapai $12.13 \%$ saat 72 jam mengalami penurunan mencapai $11.13 \%$ dan pada waktu 96 jam fermentasi terjadi penurunan mencapai 10.16\%. Menurut Desrosier (1988), pada proses fermentasi pati terlebih dahulu diubah menjadi sukrosa (maltosa), kemudian dirombak menjadi monosakarida (glukosa dan fruktosa) kemudian diubah menjadi alkohol, asam asetat, air dan senyawa lainnya. Hal ini menunjukkan bahwa semakin lama proses fermentasi berlangsung maka semakin banyak monosakarida yang diubah menjadi senyawa lain, sehingga kadar gula reduksi yang dihasilkan pada tapai talas bentul semakin menurun

\section{KESIMPULAN DAN SARAN \\ Kesimpulan}

Pada penelitian "Diversifikasi Talas Bogor (Colocasia esculenta (L) Schott) sebagai Upaya Olahan Produk Tapai Khas Bogor" dapat disimpulkan bahwa:

Hasil analisa karbohidrat dari tiga jenis talas (talas bentul, talas mentega dan talas sutra) yang akan dilakukan fermentasi, didapati kadar karbohidrat dari talas bentul lebih tinggi yaitu $23.59 \%$. Tingginya kandungan karbohidrat pada talas dapat menghasilkan tapai dengan tekstur yang bagus. Berdasarkan kandungan kimia yang terdapat pada tapai, didapati waktu optimum fermentasi adalah saat umur fermentasi 48 jam, dengan kandungan kadar air sebesar $21.94 \%$, abu $2.11 \%$, lemak $1.78 \%$, protein $2.96 \%$, karbohidrat $21.94 \%$, gula total $13.99 \%$, alkohol $6.03 \%$ serat pangan $2.28 \%$ dan nilai $\mathrm{pH}$ sebesar $5.48 \%$.

\section{Saran}

1. Perlu dilakukan penelitian lanjutan mengenai proses penyimpanan dan proses pengemasan apabila prodak tapai talas ingin dipasarkan.

2. Perlu dilakukan penelitian lanjutan terhadap optimasi perebusan talas sebelum ditaburi ragi, agar mendapatkan kandungan serat pangan yang lebih optimum.

\section{DAFTAR PUSTAKA}

Astawan M. (2004). Sehat bersana aneka sehat pangan alami. Tiga serangkai. Solo.

Desrosier, W.N. (1998). Teknologi Pengawetan Pangan. Diterjemahkan oleh Muchji Muljohardjo. UI-press.

Indastri, D. (2004). Pemanfaatan Tepung Talas Belitung (Xanthosoma sagittifolium) dalam Pembuatan Cookies. Bogor: Fakultas Teknologi Pertanian, IPB.

Judoamidjojo M., A. A. Darwis dan E. G. Sa'id. (1992). Teknologi Fermentasi. Rajawali Press, Jakarta.

Julianto. (2014). Bioindustri Umbi Talas. Jakarta: Tabloid Sinar Tani.

Kuswara. (2002). Buku Kuliner Populer. Kudapan enak dari singkong, ubi, kentang dan Talas. Tim Dapur Gramedia Jakarta.

Lingga. (1989). Bertanam Ubi-ubian. Jakarta: Penebar Swadaya.

Richana, Nur. (2012). Manfaat umbiumbian Indonesia. Bandung: Nuansa

Rukmana dan Yuniarsih. (2001). Aneka Olhan Ubi Kayu. Yogyakarta: Kanisius

Santosa Agus dan Cucut Prakoso. (2010). Karakteristik tapai buah sukun hasil fermentasi menggunakan Ragi yang berbeda. Magistra No. 73 Th. XXII, September 2010 ISSN: 0215-9511

Setyohadi. (2006). Proses Mikrobiologi Pangan (Proses Kerusakan dan Pengolahan). USU-Press, Medan.

Sitompul S.M dan Guritno B. (1995). Analisis Pertumbuhan Tanaman. Gadjah Mada University Press. Yogyakarta.

Skoog, D.A., (1985). Principles of Instrumental Analysis. Saunder College Publishing: Japan.

Suwaryono O dan Yusti I. (1987). Fermentasi Bahan Makanan Tradisional. PAU Pangan dan Gizi. Universitas Gajah Mada, Yogjakarta. 